\title{
IMMEDIATE COMPLICATIONS AFTER 88 HEPATECTOMIES - BRAZILIAN CONSECUTIVE SERIES
}

\author{
Complicações imediatas após 88 hepatectomias - série consecutiva Brasileira
}

Enio Campos AMICO, José Roberto ALVES, Samir Assi JOÃO, Priscila Luana Franco Costa GUIMARÃES, Joafran Alexandre Costa de MEDEIROS, Élio José Silveira da Silva BARRETO

From the Hospital Universitário Onofre Lopes, Universidade Federal do Rio Grande do Norte (University Hospital Onofre Lopes, Federal University of Rio Grande do Norte), Natal, RN, Brazil

HEADINGS - Hepatectomy. Postoperative complications. Morbidity. Mortality.
ABSTRACT - Background: Hepatectomies have been increasingly recommended and performed in Brazil; they present great differences related to immediate complications. Aim: Assessing the immediate postoperative complications in a series of 88 open liver resections. Method: Prospective database of patients subjected to consecutive hepatectomies over nine years. The post-hepatectomy complications were categorized according to the Clavien-Dindo classification; complications presenting grade equal to or greater than 3 were considered major complications. Hepatic resections involving three or more resected liver segments were considered major hepatectomies. Results: Eighty-four patients were subjected to 88 hepatectomies, mostly were minor liver resections (50 cases, 56.8\%). Most patients had malignant diseases (63 cases; $71.6 \%$ ). The mean hospitalization time was 10.9 days (4-43). Overall morbidity and mortality rates were $37.5 \%$ and $6.8 \%$, respectively. The two most common immediate general complications were intra-peritoneal collections $(12.5 \%)$ and pleural effusion (12.5\%). Bleeding, biliary fistula and liver failure were identified in $6.8 \%, 4.5 \%$ and $1.1 \%$ of the cases, respectively, among the hepatectomy-specific complications. Conclusion: The patients operated in the second half of the series showed better results, which were apparently influenced by the increased surgical expertise, by the modification of the hepatic parenchyma section method and by the increased organ preservation.

\section{Correspondence:}

Enio Campos Amico,

e-mail:ecamic@uol.com.br

Financial source: none

Conflicts of interest: none

Received for publication: 16/02/2016 Accepted for publication: 15/05/2016

DESCRITORES - Hepatectomia Complicações pós-operatórias. Morbidade. Mortalidade.
RESUMO - Racional: No Brasil as hepatectomias têm sido cada vez mais indicadas e realizadas, apresentando grandes diferenças relacionadas às complicações imediatas. Objetivo: Avaliar as complicações pós-operatórias imediatas em uma série de 88 ressecções hepáticas abertas. Método: Foi utilizada uma base de dados prospectiva de pacientes submetidos à hepatectomias consecutivas em nove anos. As complicações pós-hepatectomia seguiram a Classificação de Clavien-Dindo, sendo consideradas complicações maiores aquelas as quais apresentaram grau igual ou maior que 3. Foram consideradas hepatectomias maiores as ressecções hepáticas que envolveram três ou mais segmentos hepáticos ressecados. Resultados: Oitenta e quatro pacientes foram submetidos a 88 hepatectomias, sendo a maioria ressecções hepáticas menores (50 casos; $56,8 \%$ ). A maior parte dos pacientes apresentou doença maligna (63 casos; $71,6 \%$ ). O tempo médio de internação foi de 10,9 dias (4-43). A taxa de morbidade e mortalidade global foi, respectivamente, de $37,5 \%$ e $6,8 \%$. As duas complicações gerais imediatas mais frequentes foram as coleções intraperitoneais (12,5\%) e o derrame pleural (12,5\%). Já as complicações específicas das hepatectomias - sangramento, fístula biliar e insuficiência hepática - foram respectivamente de 6,8\%, 4,5\% e 1,1\% dos casos. Conclusão: Os pacientes operados na segunda metade da presente casuística tiveram melhores resultados influenciados, aparentemente, pela maior experiência cirúrgica, modificação do método de secção do parênquima hepático e maior preservação do fígado.

$\mathrm{N}$ owadays, liver resections are indicated for a large number of benign and malignant diseases. The great progress made in the last 30 years was responsible for the reduction in surgery-related mortality from $10 \%$ (in the 1980 s) to less than $4 \%^{12}$. There are few studies about the consecutive series of patients operated in the same health service or by the same team of surgeons in Brazil. In addition, the hepatectomy-related complication rates alone range from $0 \%{ }^{26}$ to $56.5 \%$, and it may suggest possible methodological biases in such studies.

The aim of this study was to present the results of post-hepatectomy complications in a consecutive series of patients.

\section{METHOD}

This research was approved by the University Hospital Onofre Lopes Ethics Committee of the Federal University of Rio Grande do Norte, Natal, RN, Brazil. It was based on the prospective database of patients subjected to consecutive liver resections 
(through laparotomy), which were performed by the main author (ECA), from July 2006 to July 2015, at Onofre Lopes University Hospital, Federal University of Rio Grande do Norte and Casa de Saúde São Lucas Hospital, Natal, RN, Brasil. The following information were collected and analyzed: the clinical features of the patients and of the underlying diseases, the liver resection type, the associated surgical procedures, the minor or major postoperative complications, need of blood transfusion, the hospitalization time, and the mortality up to 90 postoperative days.

The preoperative assessment of the cardiovascular pulmonary and renal systems, as well as of the patient's nutritional status, was common and standard in all patients subjected to hepatectomy, with few specific changes related to the underlying disease. Only patients with compensated cirrhosis and hepatocellular carcinoma, without portal hypertension (Child A), were taken into consideration for surgical treatment.

There were at least 30 days between the last chemotherapy cycle and the surgical treatment in cases of patients undergoing chemotherapy for colorectal liver metastasis. The preoperative portal embolization was assessed in cases in which a small liver residue was predicted.

Patients with cholangiocarcinoma, supposed to undergo right hepatectomy, were subjected to preoperative external biliary drainage. They were operated just after the total bilirubin values got below $5 \mathrm{mg} / \mathrm{dl}$.

The hepatectomy surgical procedure was standardized. General anesthesia associated with epidural anesthesia was applied to non-cirrhotic patients supposed to undergo major liver resection. A large-calibervenous vascular access (caliber $=8.5$ $\mathrm{Fr}$ ) was set in the right internal jugular vein and in the arterial access (left radial artery) in order to measure the mean arterial pressure of all patients during the anesthetic induction. Restricted intravenous hydration was performed during the liver preresection stage in order to keep the central venous pressure low (less than $5 \mathrm{mmHg}$ ). The Pringle maneuver was selectively used in cases of substantial bleeding in the hepatic parenchyma resection stage. The "Glissonian Approach" was used in the hepatic pedicle ligation, whenever possible. Preference was given to the extrahepatic dissection of the hepatic veins. The Silkclasy technique ${ }^{10}$ was used to section the hepatic parenchyma in the first half of the series (first 44 cases), whereas the ultrasonic aspirator was used in the second half of it (CUSA ${ }^{\oplus}$ Excel + Ultrasonic Surgical Aspirator). Metal clips were used in the hemostasis of small blood vessels in the hepatic parenchyma, whenever they were available. Most recently, the linear stapler was used in a few cases (the last 10 cases) to section the Glissonian pedicle or the hepatic veins of the patients. The routine postoperative drainage was performed using silicone laminar drains, except for cases in which minor resections were mainly performed in the left hepatic lobe.

According to the Clavien-Dino classification, the postoperative complications were categorized as major, whenever they presented grade equal to or greater than 3, and as minor, whenever the grade was lower than $3^{4}$. Cases demanding necessary resection in 3 or more liver segments were considered major hepatectomies ${ }^{11}$.

The diagnosis of post-hepatectomy complications such as bleeding, biliary fistula and liver failure, was made according to the International Study Group for Liver Surgery 13,21,22. Thus, the post-hepatectomy bleeding was defined as more than 3 $\mathrm{g} / \mathrm{dl}$ hemoglobin level decrease at the end of the surgery, in comparison to the preoperative levels; and/or as the need of postoperative erythrocyte transfusion due to hemoglobin decrease, and/or as the invasive re-intervention to control bleeding. The post-hepatectomy liver failure was defined as the hepatic function deterioration characterized by increased INR (international normalized ratio); or as the need of injecting clotting factors to keep the INR normal; or as the occurrence of hyperbilirubinemia from the fifth postoperative day on. The post-hepatectomy biliary fistula was defined as the presence of intra-peritoneal liquid or of liquid from the abdominal drain presenting high total bilirubin levels (at least three times higher than the serum level) from the third postoperative day on; or as the need for surgery or interventional radiology to drain a bile collection; or as the re-operation due to biliary peritonitis.

Mortality was taken into consideration whenever the death occurred within the first 90 postoperative days.

\section{RESULTS}

Eighty-four patients were subjected to 88 hepatectomies. Their mean age was 54.01 years (14-89) and most of them were women ( $n=55 ; 62.5 \%)$. Six were diagnosed with cirrhosis. Most had malignant diseases $(n=63 ; 71.6 \%)$; colorectal metastasis and hepatocellular carcinoma appeared most often (Table 1).

TABLE 1 - Distribution of diseases that were the basis for the indication of 88 hepatectomies in nine years

\begin{tabular}{|l|c|}
\hline \multicolumn{1}{|c|}{ Hepatectomy indications } & Frequency \\
\hline Benign diseases & 6 \\
\hline Hepatic adenoma & 6 \\
\hline Biliary cystadenoma & 4 \\
\hline Intrahepatic lithiasis & 3 \\
\hline Focal nodular hyperplasia & 2 \\
\hline Hemangioma & 1 \\
\hline Liver trauma & 1 \\
\hline Latrogenic bile duct injury & 1 \\
\hline Acute calculous cholecystitis & 1 \\
\hline Non-specific benign disease & \\
\hline Malignant diseases & \\
\hline Primary: & 9 \\
\hline Hepatocellular carcinoma & 7 \\
\hline Gallbladder adenocarcinoma & 4 \\
\hline Cholangiocarcinoma & 1 \\
\hline Malignant epithelioid cell tumor & \\
\hline Secondary: & 30 \\
\hline Metastatic colorectal cancer & 5 \\
\hline Metastatic neuroendocrine tumor & 3 \\
\hline Metastatic breast cancer & 1 \\
\hline Metastatic gastrointestinal stromal tumor & 1 \\
\hline Metastatic squamous cell carcinoma of the cervix & 1 \\
\hline Metastatic squamous cell carcinoma of the anal canal & 1 \\
\hline Metastatic gallbladder adenocarcinoma & 88 \\
\hline TOTAL & \\
\hline
\end{tabular}

Twenty-eight (28) patients (31.81\%) were subjected to some surgical procedure associated with hepatic resections; biliodigestive anastomosis $(n=6)$ and colon resection $(n=4)$, respectively, were the most often performed ones.

Fifty (56.8\%) minor and 38 (43.2\%) major hepatectomies were performed (Table 2, Figures 1 and 2).

Twenty-seven (27) hepatectomies (30.7\%) required blood transfusion (2.3 units of red blood cell concentrate per patient on average; ranging from 1 to 8 blood bags). Twenty-three (23) out of these cases required up to 2 blood bags. The patients remained 2.4 days $(0-17)$, on average, in the intensive care unit, and the mean postoperative hospital stay was 10.9 days (4-43). They were divided according to the hepatic parenchyma dieresis technique and those who were operated in the second half of the series (the last 44 cases in the series), using the CUSA ${ }^{\oplus}$ type scalpel, showed better results (Table 3 ). 
TABLE 2 - Distribution of the 88 hepatectomies performed in nine years, according to liver resection type

\begin{tabular}{|c|c|}
\hline Hepatectomy types & Frequency \\
\hline \multicolumn{2}{|l|}{ (Resected liver segments) } \\
\hline \multicolumn{2}{|l|}{ Minor hepatectomies } \\
\hline \multicolumn{2}{|l|}{ * Monosegmentectomies: } \\
\hline Seg II & 1 \\
\hline Seg III & 3 \\
\hline Seg IV & 2 \\
\hline Seg IVb & 2 \\
\hline Seg V & 3 \\
\hline Seg VI & 2 \\
\hline Seg VII & 2 \\
\hline Enucleation & 2 \\
\hline \multicolumn{2}{|l|}{ * Bisegmentectomies: } \\
\hline Seg II and III & 14 \\
\hline Seg IV and VIII & 1 \\
\hline Seg IVb and V & 7 \\
\hline Seg V and VI & 5 \\
\hline Seg VI and VII & 3 \\
\hline Seg VII and VIII & 3 \\
\hline \multicolumn{2}{|l|}{ Major hepatectomies } \\
\hline Right hepatectomy & 9 \\
\hline Right hepatectomy + caudate & 2 \\
\hline Right trisegmentectomy & 1 \\
\hline Mesohepatectomy & 2 \\
\hline Left hepatectomy + caudate & 4 \\
\hline Left hepatectomy & 14 \\
\hline Resection of segments II, III, IVb and V & 1 \\
\hline Resection of segments II, III and VII & 2 \\
\hline Resection of segments II, VI and VII & 1 \\
\hline Resection of segments IVb, VII and VIII & 1 \\
\hline Resection of segments V, VI and VIII & 1 \\
\hline TOTAL & 88 \\
\hline
\end{tabular}

Seg=resection of liver segment(s); + =associated with resection

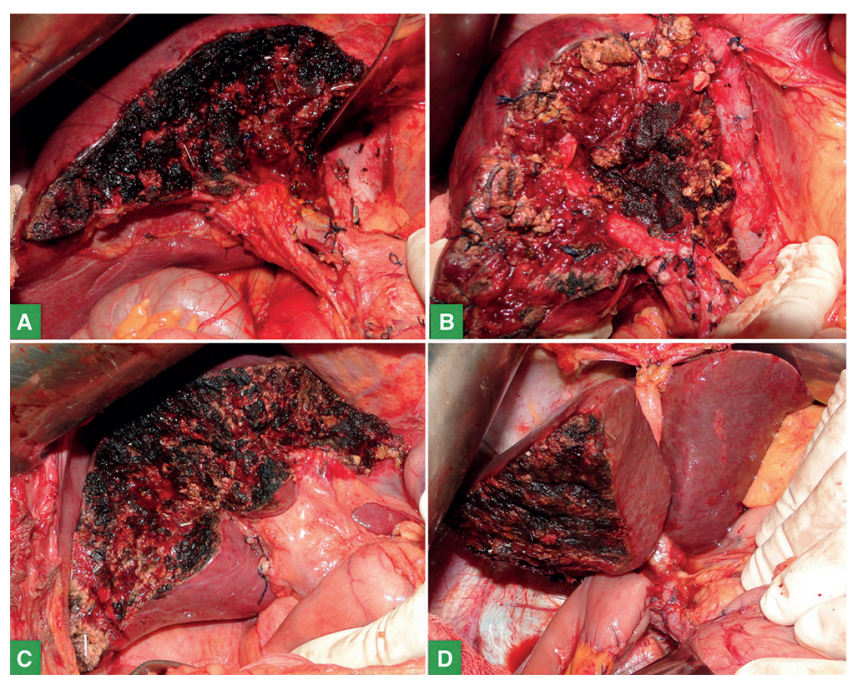

FIGURE 1 - Major hepatectomy illustrative cases in final aspect of liver resections at the end of the intraoperative period: A) left hepatectomy + caudate resection + lymphadenectomy of thehepatic hilum dueto intrahepatic cholangiocarcinoma; B) left hepatectomy + caudate resection due to metastatic colon adenocarcinoma with highlighting that the resection extends to the Glissonian pedicle of the right hemi-liver in order to obtain a negative margin; $C$ ) resection of liver segments II + III + IVb + V due to metastatic colon adenocarcinoma; D) right hepatectomy + caudate resection + lymphadenectomy + resection of the biliary tract and Roux-en-Y reconstruction due to cholangiocarcinoma in the confluence of the hepatic ducts (Klatskin Tumor).
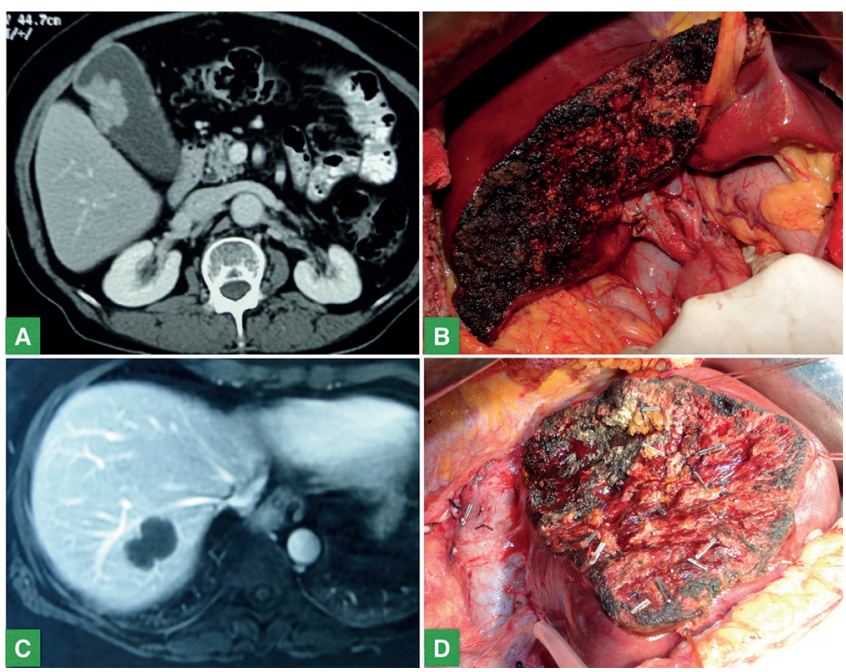

FIGURE 2 - Minor hepatectomy illustrative cases: A) abdomen tomography showing gallbladder wall vegetation through enhanced intravenously administered contrast; B) final aspect of IVb + V bisegmentectomy + lymphadenectomy of the hepatic hilum with anatomopathological examination resulting in gallbladder adenocarcinoma; C) abdominal tomography showing hypodense lesion in segment VII topography with involvement of the right hepatic vein in patient with history of invasive ductal breast carcinoma; D) final appearance of liver segment VII resection associated with resection of the right hepatic vein with anatomopathological examination resulting in metastatic adenocarcinoma

TABLE 3 - Comparison between results of the first half (the 1st 44 hepatectomies) and the second half (the last 44 hepatectomies) in patients operated in nine years

\begin{tabular}{|c|c|c|}
\hline Sample features & First half & $\begin{array}{l}\text { Second } \\
\text { half }\end{array}$ \\
\hline$(n=88)$ & $(n=44)$ & $(n=44)$ \\
\hline Age (mean) & $\begin{array}{c}55.2 \\
\text { years }\end{array}$ & 52.4 years \\
\hline Malignant/benign disease ratio & $32 / 12$ & $31 / 13$ \\
\hline Major/minor hepatectomy ratio & $21 / 23$ & $17 / 27$ \\
\hline Right/left resection ratio & $14 / 22$ & $15 / 18$ \\
\hline Mean hospital stay & 12.7 days & 9.1 days \\
\hline $\begin{array}{l}\text { Number (\%) of patients who received [ ] } \\
\text { red blood cell transfusion }\end{array}$ & 15 (34\%) & $12(27.3 \%)$ \\
\hline $\begin{array}{l}\text { Mean number of [ ] red blood cell bags } \\
\text { per patient }\end{array}$ & $\begin{array}{l}3 \text { blood } \\
\text { bags }\end{array}$ & $\begin{array}{l}1.75 \text { blood } \\
\text { bags }\end{array}$ \\
\hline Mean postoperative ICU time & 2.9 days & 1.8 days \\
\hline Incidence of complications (overall) & $43.20 \%$ & $31.80 \%$ \\
\hline
\end{tabular}

Complications directly related to the

hepatectomies:

\begin{tabular}{|l|c|c|}
\hline - Incidence of intra-abdominal collection & $15.9 \%$ & $9.1 \%$ \\
\hline - Incidence of postoperative bleeding & $11.4 \%$ & $2.3 \%$ \\
\hline - Incidence of biliary fistula & $2.3 \%$ & $6.8 \%$ \\
\hline - Incidence of liver failure & $2.3 \%$ & $0.0 \%$ \\
\hline Incidence of major complications & $20.40 \%$ & $9.10 \%$ \\
\hline Incidence of deaths & $11.30 \%$ & $2.30 \%$ \\
\hline
\end{tabular}

$\mathrm{n}=$ number of hepatectomies performed; [ ] = concentrate; \%=percentage of cases; $\mathrm{ICU}=$ intensive care unit 
TABLE 4 - Distribution of postoperative complications after 88 hepatectomies

\begin{tabular}{l|c|} 
& Prequency \\
\hline complications & $\mathrm{n}(\%)$ \\
\hline Intraperitoneal collection & $11(12.5 \%)$ \\
\hline Pleural effusion & $11(12.5 \%)$ \\
\hline Bleeding & $6(6.8 \%)$ \\
\hline Surgical wound infection & $5(5.7 \%)$ \\
\hline Biliary fistula & $4(4.5 \%)$ \\
\hline Incisional hernia & $4(4.4 \%)$ \\
\hline Pneumonia & $3(3.4 \%)$ \\
\hline Urinary tract infection & $2(2.3 \%)$ \\
\hline Pleural empyema & $2(2.3 \%)$ \\
\hline Atelectasis & $2(2.3 \%)$ \\
\hline Acute myocardial infarction & $1(1.1 \%)$ \\
\hline Liver failure & $1(1.1 \%)$ \\
\hline Portal vein thrombosis & $1(1.1 \%)$ \\
\hline Acute intestinal obstruction & $1(1.1 \%)$ \\
\hline Liver abscess & $1(1.1 \%)$ \\
\hline Pulmonary failure & $1(1.1 \%)$ \\
\hline Pulmonary thromboembolism & $1(1.1 \%)$ \\
\hline Pneumothorax & $1(1.1 \%)$ \\
\hline Ascites & $1(1.1 \%)$ \\
\hline Central catheter infection & $1(1.1 \%)$ \\
\hline n=occurred cases; \%=percentage &
\end{tabular}

The overall morbidity and mortality rates were, respectively, $37.5 \%$ and $6.8 \%$. On the other hand, the morbidity and mortality rates related just to patients subjected to major resections were, respectively, $47.3 \%$ and $10.5 \%$, and those related to patients subjected to minor resections were, respectively, $30 \%$ and $4.0 \%$.

\section{DISCUSSION}

The first successful elective liver resection for liver tumor removal was performed in Berlin by Carl Von Langenbuch in $1887^{16}$. The first hepatectomy reports in Brazil date back to the $1950 s^{7}$. However, liver resections have become routine in surgical practice only in the last 30 years. It happened due to several advances in the medical knowledge, such as the development and improvement of complementary imaging tests, the dissemination of safe surgical and anesthetic techniques, the better postoperative care, and the improvement in knowledge about liver regeneration ${ }^{8}$. Nowadays, these advances, all together, allow performing hepatectomies with minimal morbidity and mortality rates, which is crucial to expand the hepatectomy indications, mainly in oncology and in liver transplant fields ${ }^{8}$.

Although the hepatectomy-related morbidity and mortality rates are not the only ones, they are an important efficiency marker of these procedures. Thus, the incorporation of a standardized system to identify such events is desired. The Clavien-Dindo classification has been progressively accepted since its inception in $2004^{4}$. In addition, more recent studies have validated such classification for several surgery types ${ }^{2,27,29}$ This research used this classification to categorize the overall postoperative complications, whereas the specific postoperative complications (liver failure, bleeding and biliary fistula) were categorized through definitions suggested by the International Study Group for Liver Surgery ${ }^{13,21,22}$. Therefore, the overall postoperative complication, the major complication and the mortality rates found in the current study were $37.5 \%, 14.7 \%$ and $6.8 \%$, respectively. Although the herein found complication rate is within the world average, the death rate was higher than that described in the recent national literature, i.e., it was between $1-5 \%{ }^{25}$. The death rate in the second half of the series was similar to the best national and even to the international levels, only after the sample was divided in two halves. In addition, it was almost five times lower $11.3 \%$ vs. $2.3 \%$ ) than the casuistic in the first half of the series. It is believed that there were three possible main reasons for the improved results. Firstly, the second half of the sample showed greater tendency to minor hepatectomies and followed the trend in the literature of saving the maximum amount of liver parenchyma as possible ${ }^{15}$. Secondly, there was less need of transfusion, less perioperative bleeding and less incidence of postoperative intraperitoneal collections, probably due to the ultrasonic surgical aspirator used to section the parenchyma in the second half of the series. Last, but not least, the team of surgeons and anesthetists experimented a learning curve related to the selection and monitoring of patients for surgery, besides the standardization of surgical procedures.

The major complications in this series were those with high lethality and others with less death potential. Three patients were identified in the first group; each of them presented one of the following complications: acute myocardial infarction, postoperative liver failure and thrombosis of the mesentericportal axis. All three patients died. Based on such cases, the patients presenting risk of coronary disease in the preoperative period were investigated based on higher suspicion index. In addition, the hepatic volume calculation was extended to patients subjected to right hepatectomy as a way to reduce the risk of postoperative liver failure. No factor able to be corrected through the management of patients was identified in the prevention of portal vein thrombosis, because the attachment of the falciform ligament to the abdominal wall was already used as routine practice in the right hepatectomy to avoid portal vein kinking ${ }^{14}$. The second group comprised only patients who developed bleeding, abdominal collection and biliary fistula, which led to death incidence of 33\%, 33\% and $25 \%$, respectively. The diagnosis of complication was easier in these patients and it was obtained through clinical assessment and laboratory analysis of the liquid collected from the abdominal drain. In addition, the most effective treatment comprised blood transfusions and drainage of intra-abdominal abscesses or of the biliary leakage.

Liver resections are performed at several reference services throughout Brazil; however, there are few studies showing the overall immediate results of such procedure. In most cases, such studies comprise few patients, sometimes with specific diseases or even subjected to specific types of liver resections. Often, the immediate complications are not reported or, in case they are reported, they are not evenly defined. The literature review resulted in 14 studies about patients subjected to at least 40 liver resections in Brazilian medical services in the past 20 years $(3,5,6,9,10,15,17-20,23,24,26)$.

Disregarding the study by Fernandes ${ }^{6}$, because it comprises a series of patients subjected to hepatectomy for donation in living donor liver transplants, most case series comprised patients with non-cirrhotic liver (84.3 - 100\%) and with malignant disease (48-96.6\%), fact that meets the most prevalent type of patient in the current study. The number of major hepatectomies in the other national case series was quite varying (from 9.6-61.4\%). The complications were descriptively reported in 12 studies, whereas only one ${ }^{5}$ included the Clavin-Dindo Classification in its methodology. Such fact certainly influenced the big difference evidenced in the complication rates, i.e., a range from $0-56.6 \%$. It is almost certain that the minor complications categorized as grade I were not taken into consideration in the results of the studies that did not use the Clavin-Dindo Classification, due to their small impact.

The only Brazilian study that could be compared to the herein presented series has retrospectively analyzed 129 resections in non-cirrhotic livers, $42.6 \%$ of these series were considered major hepatectomies ${ }^{5}$. The morbidity and mortality rates were $56.5 \%$ and $7.8 \%$, respectively, whereas those of the current study were $37.5 \%$ and $6.8 \%$, respectively. The mortality rate was very similar in both studies; however, the complication in the aforementioned study was higher than the herein described. The complication types also showed some differences: 1 ) this 
study found similar prevalence of pulmonary and infectious complications (both with 20.5\%), whereas Feier et al. ${ }^{5}$ found pulmonary and infectious complications in $39.7 \%$ and $28.7 \%$, respectively; 2 ) this research found biliary fistula index three times lower $(4.5 \times 13.7 \%)$ than that reported by Feier et al. ${ }^{5}$; and $3)$ this paper found bleeding rate almost three times higher $(6.8 \times 2.7 \%)$ than that found in the aforementioned study.

The biliary fistula did not represent a major problem in the herein investigated series. The methylene blue test was systematically performed after the liver resections, despite the lack of validated studies to prove its eficiency ${ }^{25}$. Diluted dye (1:3 parts of saline solution) was injected in the cystic duct during the test in order to identify its presence in the open wound of the resected liver. Whenever dye leakage was detected, a suture was performed by applying separate " $\mathrm{X}$ " stitches using Prolene $4-0^{\circledR}$. It is believed that the herein described test helped preventing postoperative biliary fistulas. The treatment in all four biliary fistula cases was conservatively conducted and based on the maintenance of the abdominal drains left at the time of surgery.

\section{CONCLUSION}

Patients operated in the second half of the series showed better results, which were apparently influenced by the increased surgical expertise, by the modification in the hepatic parenchyma section method, and by the increased organ preservation.

\section{REFERENCES}

1. Bismuth $H$, Eshkenazy $R$, Arish A. Milestones in the evolution of hepatic surgery. Rambam Maimonides Med J 2011; 2(1:e0021):1-11.

2. ClavienPA,BarkunJ, deOliveiraML, etal.TheClavien-Dindoclassification of surgical complications:five-yearexperience.AnnSurg2009;250(2):187-96.

3. Coelho JC, Claus CM, Machuca TN, Sobottka WH, Gonçalves CG. Liver resection: 10-year experience from a single institution. Arq Gastroenterol 2004; 41(4):229-33.

4. DindoD,Demartines N, ClavienPA.Classification of surgical complications: a new proposal with evaluation in a cohort of 6336 patients and results of a survey. Ann Surg 2004; 240(2):205- 13.

5. Feier FH. Predição de morbidade após hepatectomia: validação externa doescore derisco deBreitenstein.Dissertação deMestrado,Universidade Federal do Rio Grande do Sul, 2012:1-69.

6. Fernandes R, Pacheco-Moreira LF, Enne M, Steinbrück K, Alves JA, Filho $\mathrm{GD}$, et al. Surgical complications in 100 donor hepatectomies for living donor liver transplantation in a single Brazilian center. Transplant Proc 2010; 42(2):421-3

7. Fonseca-Neto OCL. Hepatectomias. RBM 2007; 64(9):417-21.

8. Fortner JG1, Blumgart LH. A historic perspective of liver surgery for tumors at the end of the millennium. J Am Coll Surg 2001; 193(2):210-22.

9. Guerra EE, Pereira-Lima LM. Ressecções hepáticas com oclusão vascular aferente: análise de fatores de risco. Rev Col Bras Cir 2001; 28(5):347-55.

10. Herman $P$, Machado MA, Machado MC. Silkclasy: a simple way for liver transectionduring anatomichepatectomies.JSurg Oncol2007;95(1):86-9.
11. Imamura H, Seyama Y, Kokudo N, Maema A, Sugawara Y, Sano K, et al. One thousand fifty-six hepatectomies without mortality in 8 years. Arch Surg 2003; 138(11):1198-206.

12. Kingham TP, Correa-Gallego C, D'Angelica MI, Gönen M, DeMatteo RP, Fong $Y$, et al. Hepatic parenchymal preservation surgery: decreasing morbidity and mortality rates in 4,152 resections for malignancy. J Am Coll Surg 2015; 220(4):471-9.

13. Koch M, Garden OJ, Padbury R, Rahbari NN, Adam R, Capussotti L, et al Bile leakage after hepatobiliary and pancreatic surgery: a definition and grading of severity by the International Study Group of Liver Surgery. Surgery 2011; 149(5):680-8.

14. Kuboki S, Shimizu H, Ohtsuka M, Kato A, Yoshitomi H, Furukawa K, et al. Incidence, risk factors, and management options for portal vein thrombosis after hepatectomy: a 14-year, single-center experience. Am J Surg 2015; 210(5):878-85

15. Lacerda CF, Bertulucci PA, Oliveira AT. Totally laparoscopic liver resection: new Brazilian experience. Arq Bras Cir Dig 2014; 27(3):191-5.

16. Langenbuch C. Ein Fall von Resektion eines linksseitigen Schnurlappens der Leber, Heilung. Berl Klin Wochenschr 1888; 25:37-38

17. Lopes-Junior AG, Belebecha V, Jacob CE. Hepatectomy: a critical analysis on expansion of the indications. Arq Bras Cir Dig 2014; 27(1):47-52.

18. MachadoMAC;MakdissiFF;SurjanRCF.Hepatectomiavideolaparoscópica. Experiência pessoal com 107 casos. Rev Col Bras Cir 2012; 39(6): 483-8.

19. Machado MCC; Herman P; Machado MAC; Bacchella T; Cunha JEM; Pinotti HW. Hepatectomia - Indicações e resultados imediatos: Estudo de 114 pacientes. Rev Col Bras Cir 1997; 24(5):317-22.

20. Pais-Costa SR, Farah JFM, Artigiani-Neto R, Franco MIF, Martins SJ, Goldenberg A. Adenocarcinoma da vesícula biliar: avaliação dos fatores prognósticos em 100 casos ressecados no brasil. Arq Bras Cir Dig 2012; 25(1):13-9.

21. Rahbari NN, Garden OJ, Padbury R, Brooke-Smith M, Crawford M, Adam $\mathrm{R}$, et al. Posthepatectomy liver failure: a definition and grading by the International Study Group of Liver Surgery (ISGLS). Surgery 2011; 149(5):713-24.

22. Rahbari NN, Garden OJ, Padbury R, Maddern G, Koch M, Hugh TJ, et al. Post-hepatectomy haemorrhage: a definition and grading by the International Study Group of LiverSurgery(ISGLS).HPB2011;13(8):528-35.

23. Resende V; Rezende-Neto JB; Fernandes JS; Cunha-Melo JR. Avaliação da morbidade e da mortalidade após ressecções hepáticas. Rev Col Bras Cir 2011; 38(5):323-6.

24. Ribeiro HS, Stevanato-Filho $P R$, Costa Jr WL, Diniz AL, Herman $P$, Coimbra FJ. Prognostic factors for survival in patients with colorectal liver metastases: experience of a single brazilian cancer center. Arq Gastroenterol 2012; 49(4):266-72.

25. Russell MC. Complications following hepatectomy. Surg Oncol Clin N Am 2015: 24(1):73-96

26. Sampaio JA, Waechter FL, Passarin TL, Kruse CK, Nectoux M, Fontes $\mathrm{PRO}$, et al. É possível diminuir o sangramento em hepatectomias sem a realização de exclusão vascular total ou parcial? Resultados do uso de radiofrequência bipolar com agulhas resfriadas. Arq Bras Cir Dig 2011; 24(2):159-63.

27. Yoon PD, Chalasani V, Woo HH. Use of Clavien-Dindo classification in reportingand grading complicationsafterurologicalsurgical procedures: analysis of 2010 to 2012. J Urol 2013; 190(4):1271-4.

28. Zanotelli ML, Feier F, Nunes AG. Cirurgia hepática: experiência em 9 anos no hospital de clínicas de Porto Alegre. Rev HCPA 2010; 30(1): 31-5.

29. Zhou J, Yu P, Shi Y, Tang B, Hao Y, Zhao Y, Qian F. Evaluation of ClavienDindo classification in patients undergoing total gastrectomy for gastric cancer. Med Oncol 2015; 32(4:120):1-7. 